\title{
Efek Pemberian Meloxicam yang Diberikan Selama Fase Inflamasi terhadap Proses Penyembuhan Tulang Tikus Paska Open Reduction Internal Fixation K-Wire Dinilai Secara Radiologis
}

\author{
Tody Pinandita, Darmadji Ismono, Yoyos Dias Ismiarto, M Rizal Chaidir \\ Departemen Orthopaedi dan Traumatologi, Fakultas Kedokteran Universitas Padjadjaran/ \\ Rumah Sakit Umum Pendidikan Dr. Hasan Sadikin Bandung
}

\begin{abstract}
Abstrak
Salah satu faktor yang menyebabkan terjadinya delayed union atau nonunion pada kasus fraktur adalah pemberian OAINS seperti Meloxicam, namun Meloxicam tetap harus diberikan selama fase inflamasi untuk mengurangi rasa nyeri dan reaksi inflamasi. Tujuan penelitian untuk menganalisis efek Meloxicam terhadap pembentukan kalus paha tikus yang diberikan selama fase inflamasi paska open reduction internal fixation $K$-wire dinilai secara radiologis. Penelitian merupakan uji eksperimental laboratorium pada 33 tikus jantan dengan metode pengambilan sampel rancang acak sederhana. Penelitian dilakukan di Bagian Farmakologi Klinik FK-Unpad, Departemen/SMF Orthopaedi dan Traumatologi FK Unpad/RSHS Bandung dan Departemen/ SMF Radiologi FK Unpad/RSHS Bandung, mulai dari 25 Juli 2017 hingga 7 September 2017. Penelitian menunjukkan kelompok kontrol dan perlakuan I (Meloxicam 7 hari) memiliki skor Tiedeman lebih baik dibandingkan kelompok perlakuan II (Meloxicam 30 hari) pada hari ke-30 ( $p<0.05)$ dan ke-45 ( $\mathrm{p}<0.05)$, diameter kalus kelompok kontrol dan perlakuan I lebih baik dibandingkan perlakuan II pada hari ke-30 (p $<0.05)$ dan hari ke-45 ( $\mathrm{p}<0.05)$, volume kalus kelompok kontrol dan perlakuan I lebih baik pada hari ke-30 ( $<0.05)$ dan hari ke-45 ( $\mathrm{p}<0.05)$. Kesimpulan penelitian adalah pemberian Meloxicam selama fase inflamasi paska ORIF intramedullary $K$-wire setelah terjadi fraktur, tidak mempengaruhi proses penyembuhan fraktur.
\end{abstract}

Kata kunci : Fase inflamasi , Meloxicam, paska ORIF, penyembuhan fraktur

\section{The Effect of Meloxicam Administration During Inflammation Phase to Healing Process of Mice Bone After Open Reduction Internal Fixation K-Wire Assessed Radiologically}

\begin{abstract}
One of the factors causing delayed union or nonunion in the case of a fracture is the administration of NSAIDs such as Meloxicam, but Meloxicam should still be given during the inflammatory phase to reduce pain and inflammatory reactions. The aim of this study was to analyze the effect of Meloxicam on callus formation of femur's rat given during the inflammatory phase after open reduction of internal fixation K-wire was assessed radiologically. The study was a laboratory experimental test in 33 male rats with a simple random design sampling method. The research was conducted in pharmacology clinic laboratorium of FK Unpad, Department / SMF Orthopedic and Traumatology FK Unpad / RSHS Bandung and Department / SMF Radiology FK Unpad / RSHS Bandung, starting from July 25, 2017 until 7 September 2017. The study showed that control and experimental group I (Meloxicam 7 days) had better Tiedeman score than experimental group II (Meloxicam 30 days) on day $30(p<0.05)$ and $45(p<0.05)$, callus diameter of control group and experimental group I was better than experimental group II on day $(P<0.05)$ and day $45(p<0.05)$, callus volume of control group and exeperimental group I was better on day $30(p<0.05)$ and day $45(p<0.05)$. The conclusion of this study was the administration of Meloxicam during inflammation phase post-ORIF after fracture did not affect the fracture healing process.
\end{abstract}

Keywords : Fracture healing, inflammation phase, Meloxicam, post-ORIF

Korespondensi:

Tody Pinandita, dr

Departemen Orthopaedi dan Traumatologi, Fakultas Kedokteran Universitas Padjadjaran/

RSUP Dr. Hasan Sadikin Bandung

Jl. Pasteur No 38 Bandung, Jawa Barat Indonesia. 40161

Mobile : 082121291817

Email : tody_pinandita@yahoo.com 


\section{Pendahuluan}

Penggunaan Obat Anti Inflamasi Non Steroid (OAINS) sering dijumpai di rumah sakit di Indonesia, karena memiliki tiga efek terapi, yaitu sebagai anti inflamasi, anti piretik dan analgesik. Penggunaan OAINS ini mulai dari praktek pribadi, puskesmas hingga rumah sakit. OAINS dipilih dalam bidang Orthopaedi, terutama pada kasus nyeri akut paska trauma atau nyeri kronis pada osteoarthritis dan rheumatoid arthritis, karena OAINS memiliki potensi analgesik dan efek anti inflamasi yang baik, serta efek samping yang lebih sedikit bila dibandingkan dengan analgesik dari golongan opioid. Di Amerika Serikat, hampir 111.400.000 resep OAINS dibuat setiap tahunnya dengan nilai penjualan sebesar hampir 5 miliar Dolar Amerika Serikat. ${ }^{1-3}$

Di Amerika Serikat, angka kejadian delayed union atau nonunion diperkirakan mencapai 5\% sampai $10 \%$ dari seluruh kasus patah tulang. Banyak faktor yang dapat mengintervensi proses penyembuhan patah tulang dan mengakibatkan terjadinya delayed union atau nonunion..$^{1-3}$

Faktor yang menyebabkan kegagalan penyembuhan tulang dibagi menjadi faktor biologis dan faktor mekanis. Faktor biologis berupa pola fraktur, fraktur terbuka atau tertutup, infeksi, penyakit kronis, penyakit metabolik dan penyakit gangguan imunitas, pola hidup seperti merokok dan penyalahgunaan alkohol. Faktor mekanis berupa mekanisme stress strain, mobilisasi fraktur, reduksi fraktur, fiksasi fraktur, terapi operatif dan terapi konservatif. Salah satu faktor penting untuk mencapai hasil yang baik dari proses penyembuhan tulang agar terhindar dari resiko terjadinya kegagalan adalah program rehabilitasi setelah dilakukan operasi fiksasi internal. Namun, terkadang pasien tidak melakukan rehabilitasi seperti yang sudah diprogramkan oleh tim dokter karena keluhan nyeri yang muncul selama fase inflamasi (2-7 hari) setelah terjadi trauma atau setelah dilakukan open reduction internal fixation. Untuk mengatasi keluhan nyeri selama fase inflamasi tersebut, maka diberikanlah OAINS. ${ }^{4}$

Salah satu faktor yang dapat mempengaruhi proses penyembuhan tulang adalah beberapa agen farmakologis, di antaranya adalah pemberian OAINS. ${ }^{4}$ Mekanisme utama OAINS sebagai analgetik dan anti inflamasi adalah menghambat biosintesis prostaglandin. Hasil dari konversi asam arakhidonat menjadi prostaglandin adalah munculnya rasa nyeri dan reaksi inflamasi. Pada proses penyembuhan tulang, prostaglandin ini memegang peranan penting dalam metabolisme tulang baik melalui aktivitas osteoblas dan osteoklasnya. Apabila siklooksigenase-2 ini terhambat produksinya oleh berbagai sebab, termasuk oleh OAINS, maka peran prostaglandin dalam metabolisme tulang pun akan terganggu. ${ }^{5}$

OAINS yang sering digunakan dalam bidang Orthopaedi adalah Meloxicam, Meloxicam sering digunakan sebagai analgetik dan anti inflamasi yang diberikan setelah operasi fiksasi patah tulang maupun untuk pengobatan jangka panjang pada kasus arthritis. Seperti halnya golongan lain dari OAINS, cara kerja utama dari Meloxicam ini adalah inhibisi dari enzim siklooksigenase. OAINS menghambat enzim siklooksigenase sehingga konversi asam arakhidonat menjadi PGG2 terganggu. Meloxicam dan OAINS lainnya diberikan selama masa inflamasi (2-7 hari) untuk mengurangi efek dari proses inflamasi tersebut. Namun dari pengamatan peneliti di poliklinik Orthopaedi RSHS, banyak pasien paska operasi pemasangan fiksasi interna paska fraktur yang masih mengeluhkan nyeri bahkan setelah masa inflamasi telah terlewati sehingga masih diberikan Meloxicam atau OAINS lainnya hingga jangka panjang. Hal ini didukung oleh penelitian oleh Minkowitz, dkk. disebutkan bahwa pasien masih mengalami nyeri yang menetap pada area yang terpasang implant bahkan hingga telah mencapai fase radiographic union. Penelitian lain oleh Pot, dkk. menyebutkan bahwa, hasil fungsional pada mayoritas pasien yang dilakukan ORIF pada kasus fraktur ankle sangat memuaskan namun beberapa pasien mengeluhkan hardware related complaint yang menetap. ${ }^{6,7}$

Meskipun pemberian OAINS pada kasus paska operasi fiksasi patah tulang bermanfaat sebagai analgetik dan anti inflamasi, namun salah satu efek samping dari pemberian OAINS adalah terjadinya delayed union ataupun nonunion. ${ }^{5}$ Gangguan pada proses biosintesis prostaglandin yang disebabkan oleh siklooksigenase inhibitors dapat berpengaruh besar dalam proses pembentukan kalus setelah dilakukan operasi atau setelah mengalami fraktur. Akibat dari efek negatif tersebut terhadap proses penyembuhan tulang, beberapa penulis menyarankan untuk lebih waspada bila memberikan siklooksigenase inhibitors jangka panjang. ${ }^{8-14}$ Di sisi lain, hilangnya rasa nyeri karena pemberian OAINS pada fase inflamasi juga memegang peranan penting dalam bidang Orthopaedi sebab dengan hilangnya rasa nyeri maka rehabilitasi awal dan mobilisasi segera paska operasi dapat segera dilakukan, yakni rehabilitasi awal dan mobilisasi segera memegang peranan penting dalam proses penyembuhan tulang. ${ }^{15}$ Pada beberapa dekade terakhir, sudah banyak studi yang menyebutkan bahwa OAINS memiliki peran dalam terhambatnya proses penyembuhan patah tulang, sehingga banyak dokter yang menghindari 
pemberian OAINS paska trauma ataupun paska operasi fiksasi patah tulang. ${ }^{16}$ Namun, belum banyak penelitian yang menyebutkan mengenai berapa lama pemberian OAINS yang mulai dapat menimbulkan gangguan. ${ }^{1,2}$

Selain itu, penggunaan OAINS pada kasus trauma dan paska operasi sangat diperlukan untuk mengurangi nyeri dan mengurangi efek inflamasi, karena pada dasarnya bebas nyeri merupakan hak asasi manusia yang harus terpenuhi sehingga pemberian OAINS tetap harus dilakukan. ${ }^{1,2}$

Tujuan dari penelitian ini untuk menganalisis efek Meloxicam terhadap proses penyembuhan fraktur paha tikus yang diberikan selama fase inflamasi paska open reduction internal fixation yang dinilai secara radiologis.

\section{Metode}

Penelitian ini merupakan penelitian uji eksperimental laboratorium pada hewan percobaan dengan metode pengambilan sampel rancang acak sederhana. Penelitian dilakukan di Bagian Farmakologi Klinik Fakultas Kedokteran Universitas Padjadjaran, Departemen/ SMF Orthopaedi dan Traumatologi Fakultas Kedokteran Universitas Padjadjaran/Rumah Sakit Hasan Sadikin Bandung dan Departemen/ SMF Radiologi Fakultas Kedokteran Universitas Padjadjaran/RumahSakitHasan SadikinBandung, mulai dari 25 Juli 2017 hingga 7 September 2017.

Penelitian melibatkan tiga puluh tiga tikus wistar jantan yang dibagi kedalam tiga kelompok dan dilakukan frakturisasi pada sepertiga tengah tulang femur dan di fiksasi dengan Kirschner wire. Sebelum dilakukan randomisasi, dilakukan pemilihan hewan coba berdasarkan kriteria inklusi dan eksklusi sebagai berikut:

Kriteria Inklusi

- Tikus jantan dewasa galur Wistar

- Umur 2- 4 bulan

- Kondisi sehat

- Berat badan 200-250 gram

Kriteria Eksklusi

- Tikus betina dewasa galur Wistar

- Umur $<2$ bulan dan $>4$ bulan

- Kondisi sakit

- Berat badan $<200$ gram atau $>250$ gram

Penelitian dilakukan setelah mendapatkan ethical clearence LB.04.01/A05/EC/150/V/2017 yang dikeluarkan oleh Komite Etik dan Penelitian Kesehatan RSUP Dr. Hasan Sadikin Bandung pada 15 Mei 2017 dan izin penelitian yang dikeluarkan oleh Direktur SDM dan Pendidikan RSUP Dr. Hasan Sadikin Bandung pada 10 Juli 2017.
Hewan coba kemudian dilakukan randomisasi secara rancangan acak lengkap (completely randomized design) lalu dikelompokkan menjadi 3 kelompok, yaitu: Kontrol, terdiri dari 11 ekor tikus yang diberikan placebo (aquabidestilata); Perlakuan I, terdiri dari 11 ekor tikus yang diberikan Meloxicam 0,54 mg selama 7 hari; dan Perlakuan II, terdiri dari 11 ekor tikus yang diberikan Meloxicam 0,54 mg selama 30 hari.

Pemeriksaan radiografi dilakukan pada hari ke-30 dan ke-45.

Penilaian pembentukan kalus. Foto AP dan lateral diolah kemudian dilakukan penilaian terhadap kalus, union dan remodeling berdasarkan skoring Tiedeman, dilakukan pengukuran diameter kalus dari xray femur anteroposterior (AP) dan mediolateral (ML) dan rata-rata diameter kalus AP dan ML yang dihitung dengan menjumlahkan diameter kalus anteroposterior (AP) dan diameter kalus mediolateral (ML) kemudian dibagi dua.

Pengukuran kalus lainnya dengan melakukan pengukuran volume kalus dengan menggunakan rumus volume Perkins yaitu $2 \pi r 1(r 2-r 1) l$. Dengan $r 1$ adalah panjang tulang, $r 2$ adalah panjang tulang dan kalus, dan 1 adalah panjang kalus.

Tabel 1 Skoring radiografi penyembuhan fraktur berdasarkan Tiedeman.

\begin{tabular}{ll}
\hline \multicolumn{1}{c}{ Variabel } & Poin \\
\hline Pembentukan tulang & \\
Tidak terdapat pembentukan tulang & 0 \\
$\begin{array}{l}\text { Pembentukan tulang menempati } \\
\text { 25\% defek } \\
\text { Pembentukan tulang menempati } \\
\text { 50\% defek }\end{array}$ & 1 \\
$\begin{array}{l}\text { Pembentukan tulang menempati } \\
\text { 75\% defek }\end{array}$ & 2 \\
Pembentukan tulang menempati \\
seluruh defek
\end{tabular}




\section{Hasil}

Data yang didapatkan dari penelitian kemudian diolah menggunakan SPSS. Data antar kelompok untuk skor Tiedeman, data antar kelompok untuk diameter kalus, dan data antar kelompok untuk volume kalus kemudian di analisis menggunakan uji beda Mann-Whitney Test.

Penelitian menunjukkan hasil pada kelompok kontrol dan kelompok perlakuan I memiliki ratarata skor Tiedeman yang lebih baik dari kelompok perlakuan II pada hari 30 (3.4 vs 3.9 vs 1.4 , p < 0.05 ) dan pada hari 45 (4.4 vs 4.9 vs $2.5, \mathrm{p}<0.05)$.

Tabel 2 Nilai Rata-Rata Skor Tiedeman

\begin{tabular}{lccc}
\hline & Perilaku I & Perilaku II & Kontrol \\
\hline Hari 30 & 3.4 & 3.9 & 1.4 \\
Hari 45 & 4.4 & 4.9 & 2.5 \\
\hline
\end{tabular}

Kelompok perlakuan I juga memiliki rata-rata diameter kalus yang lebih baik pada hari 30 (2.75 vs 2.3 vs $0.825, \mathrm{p}<0.05)$ dan hari 45 (3.2 vs 2.9 vs $1.125, \mathrm{p}<0.05)$,

Tabel 3 Nilai Rata-Rata Diameter Kalus

\begin{tabular}{lccc}
\hline & Perilaku I & Perilaku II & Kontrol \\
\hline Hari 30 & 2.75 & 2.3 & 0.825 \\
Hari 45 & 3.2 & 2.9 & 1.125 \\
\hline
\end{tabular}

dan rata-rata volume kalus yang lebih baik pada hari 30 (346.34 vs 255.43 vs $52.35, \mathrm{p}<0.05)$ dan hari 45 (497.14 vs 406.86 vs 99.93, $\mathrm{p}<0.05$ ).

\section{Tabel 4 Nilai Rata-Rata Volume Kalus}

\begin{tabular}{lccc}
\hline & Perilaku I & Perilaku II & Kontrol \\
\hline Hari 30 & 346.34 & 255.43 & 52.35 \\
Hari 45 & 497.14 & 406.86 & 99.93 \\
\hline
\end{tabular}

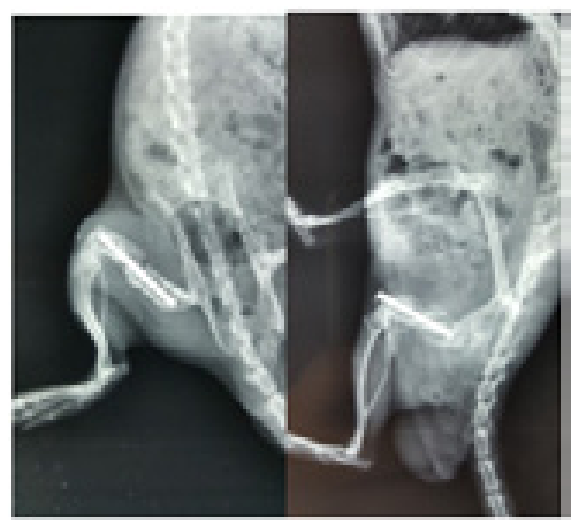

Gambar 1 Kelompok perlakuan I dengan Skor Tiedeman $4 \& 5$ pada hari $30 \& 45$

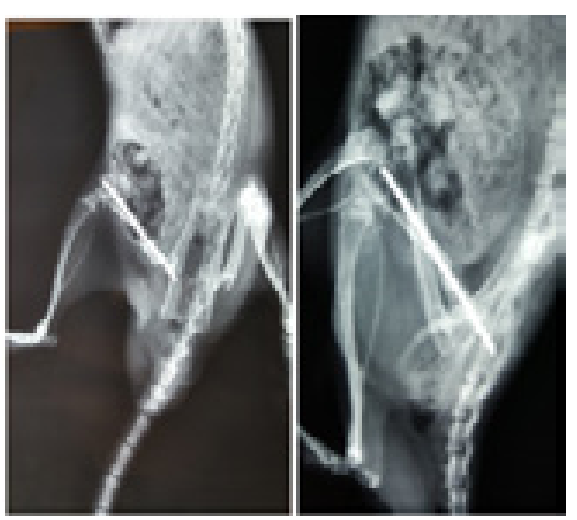

Gambar 2 Diameter kalus kelompok perlakuan II pada hari $30 \& 45$

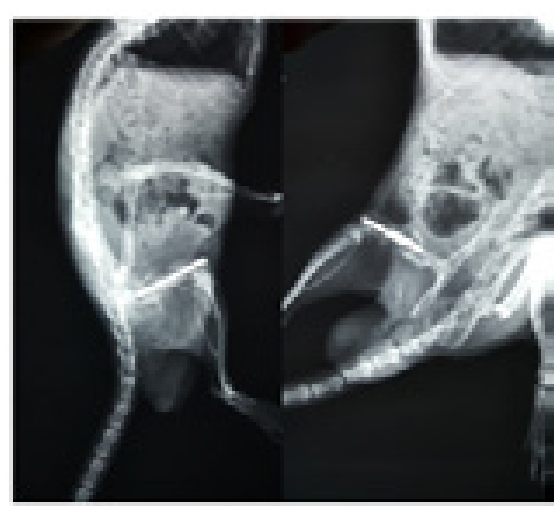

Gambar 3 Diameter kalus kelompok perlakuan I pada hari $30 \& 45$

\section{Pembahasan}

Fokus penelitian ini adalah pengaruh meloxicam terhadap penyembuhan fraktur. Penilaian penyembuhan fraktur pada penelitian ini dilakukan dengan pengukuran radiologi. Pemakaian radiologi untuk menilai penyembuhan fraktur merupakan metode yang mudah, sederhana dan praktis. Metode pengukuran yang digunakan adalah Skor Tiedeman yang mencakup pengukuran pembentukan kalus, penilaian ada tidaknya garis fraktur dan remodeling. Dilakukan juga pengukuran diameter kalus. Untuk meminimalkan timbulnya bias, penilaian dilakukan oleh seorang dokter spesialis radiologi konsultan dan analisis data dilakukan secara tersamar, penilai tidak tahu jenis perlakuan pada data yang dinilai.

Pada penelitian ini didapatkan perbedaan skor radiologis Tiedeman antara kelompok kontrol dengan kelompok perlakuan I, dengan skor 
tiedeman pada kelompok perlakuan I lebih tinggi daripada kelompok kontrol, baik pada hari ke30 maupun hari ke-45, meskipun secara statistik nilainya tidak signifikan. Hal ini mungkin terjadi karena pada kelompok kontrol tidak diberikan anti nyeri dan anti inflamasi sehingga tikus kelompok kontrol akan mengalami sensasi nyeri dan reaksi inflamasi yang lebih daripada tikus kelompok perlakuan I dan membuat tikus kelompok kontrol menjadi lebih tidak aktif daripada tikus kelompok perlakuan I. Dengan lebih aktifnya tikus pada kelompok perlakuan I, maka akan memberikan axial loading dan micro motion pada daerah fraktur yang lebih banyak pula. Axial loading dan micro motion merupakan dua hal penting dalam proses indirect healing dari suatu fraktur. Proses tersebut tidak membutuhkan reduksi secara anatomis maupun fiksasi yang kaku, dan proses tersebut akan ditingkatkan kualitasnya dengan adanya micro motion dan weight bearing. ${ }^{17} \mathrm{Hal}$ ini sesuai dengan pernyataan oleh Akritopoulos dkk yang menyatakan bahwa hilangnya rasa nyeri memegang peranan penting dalam orthopaedi karena akan memfasilitasi proses mobilisasi awal paska tindakan operasi dimana mobilisasi awal akan mendukung dalam memberikan hasil rehabilitasi yang baik. ${ }^{15}$

Pada penelitian ini didapatkan perbedaan skor radiologis Tiedeman antara kelompok kontrol dan kelompok perlakuan I dengan skor Tiedeman kelompok perlakuan II, yakni skor Tiedeman kelompok kontrol dan perlakuan I lebih besar dibandingkan dengan kelompok perlakuan II, baik pada penilaian hari ke-30 maupun hari ke-45 dan secara stastistik perbedaannya signifikan ( $p$ $>0,05$.

Pada penelitian ini juga didapat perbedaan diameter kalus, pada penilaian diameter kalus hari ke-30 dan hari ke-45 didapatkan nilai yang lebih besar pada kelompok kontrol dan kelompok perlakuan I dibandingkan dengan kelompok perlakuan II dan secara stastistik signifikan (p < $0,05)$.

Untuk penilaian penyembuhan fraktur berdasarkan volume kalus yang terbentuk juga didapatkan bahwa pemberian Meloxicam selama fase inflamasi tidak berpengaruh terhadap proses tersebut. Hal ini terlihat dari hasil penelitian yang didapatkan bahwa volume kalus kelompok kontrol dan perlakuan I lebih besar daripada volume kalus kelompok perlakuan II, baik pada saat pengukuran hari ke-30 maupun hari ke-45.

Proses penyembuhan fraktur pada kelompok perlakuan II mengalami retardasi karena diberikan Meloxicam lebih lama dibandingkan kelompok kontrol dan perlakuan I. Sementara pada kelompok kontrol dan perlakuan I, meskipun diberikan Meloxicam, namun memiliki proses penyembuhan fraktur yang lebih baik. Hal ini dimungkinkan karena pemberian Meloxicam hanya jangka pendek, maka efek penghambatan konversi asam arakhidonat menjadi Prostaglandin pun bersifat sementara. Dengan berakhirnya pemberian Meloxicam, maka Prostaglandin pun dapat dihasilkan kembali dan fungsinya sebagai regulator aktivitas osteoblas dan osteoklas dapat berjalan kembali. Penelitian ini sejalan dengan penelitian yang dilakukan oleh Karachalios, dkk. yang menyebutkan bahwa siklooksigenase-2 berperan penting dalam proses penyembuhan fraktur dan penghambatan sintesanya secara jangka panjang dengan pemberian dosis tinggi anti siklooksigenase-2 akan mengganggu proses penyembuhan fraktur tersebut. Namun pemberian dosis terapetik jangka pendek anti siklooksigenase-2 hanya berefek minor pada penyembuhan fraktur. ${ }^{18}$

Dari penelitian didapatkan bahwa pemberian Meloxicam hanya selama masa inflamasi (7 hari) tidak berpengaruh terhadap proses penyembuhan fraktur. Namun hasil penelitian ini bertolak belakang dengan beberapa penelitian yang menyebutkan bahwa penggunaan OAINS menyebabkan penghambatan proses penyembuhan tulang panjang dan fusi spinal. ${ }^{19,20}$ Penelitian Giannoudis, dkk. pada tahun 2000, pada kelompok yang mengalami nonunion didapatkan bahwa sebagian besar sampel (62.5\%) mendapatkan OAINS dalam jangka waktu panjang, sedangkan pada kelompok yang mengalami union didapatkan bahwa sampel yang mendapatkan OAINS membutuhkan waktu lebih lama untuk mencapai union dibandingkan dengan sampel yang tidak mendapatkan OAINS. ${ }^{21}$ Dietrich, dkk. menyatakan bahwa Prostaglandin berperan dalam peningkatan jumlah osteoklas, sehingga berfungsi sebagai stimulus yang kuat dalam proses resorpsi tulang, sementara Lin, dkk. menyimpulkan bahwa Prostaglandin meningkatkan proses pembentukan tulang melalui peningkatan konsentrasi osteoblas, dan OAINS menghambat proses penyembuhan tulang karena mekanisme kerjanya yang mengganggu kerja dari Prostaglandin. ${ }^{22,23}$

Gerstenfeld, dkk. menyimpulkan bahwa penghambatan siklooksigenase-2 ketika pemberian obat OAINS diperpanjang hingga hari ke-21 atau hari ke-35 maka akan menyebabkan terganggungnya proses penyembuhan fraktur, namun proses penyembuhan fraktur tidak akan terganggu bila diberikan hanya selama 7 hari. ${ }^{24}$

Keterbatasan penelitian ini adalah: Kesulitan dalam melakukan prosedur insersi intramedullary wire secara tertutup; Tingkat mobilitas yang berbeda dari tiap subjek tikus yang akan mempengaruhi proses mekanik penyembuhan 
fraktur; Pengukuran $x$-ray dilakukan secara manual dan menggunakan jangka sorong,sehingga memungkinkan terjadinya kesalahan pengukuran; serta penilaian penyembuhan fraktur hanya menggunakan radiografi, dan tidak dinilai secara biomekanik.

Kesimpulan Setelah dilakukan penelitian pengaruh pemberian Meloxicam yang diberikan selama fase inflamasi terhadap proses penyembuhan tulang tikus dinilai secara radiologis, dapat disimpulkan bahwa pemberian Meloxicam selama fase inflamasi tidak mempengaruhi proses penyembuhan tulang tikus yang dinilai secara radiologis.

\section{Daftar Pustaka}

1. Lamano-Carvalho TL. Effect of conventional and $\mathrm{COX}-2$ selective non-steroidal antiinflammatory drugs on bone healing. Acta Ortop Bras. [serial on the Internet]. 2007;15(3):166-168. Available from URL: http://www.scielo.br/aob.

2. Pountos I, Georgouli T, Calori GM, Giannoudis PV. Review Article : Do Nonsteroidal Anti-Inflammatory Drugs Affect Bone Healing? A Crtitical Analysis. The Scientific World Journal. 2012; article ID 606404. DOI: 10.1100/2012/606404.

3. Lack WD, Fredericks D, Petersen E, Donovan M, George M, Nepola J, et al. Effect of Aspirin on Bone Healing in a Rabbit Ulnar Osteotomy Model. JBJS. 2013; 95:488-96.

4. Niikura T, Lee SY, Sakai Y, Nishida K, Kuroda R, Kurosaka M. Causative factors of fracture nonunion: the proportions of mechanical, biological, patient-dependent, and patient-independent factors. Journal of orthopaedic science. 2014;19(1):120-4.

5. Reuben SS. Controversial Issues in the Perioperative Use of Non-steroidal Antiinflammatory Drugs for Orthopaedic Surgery. US orthopedics review. 2005; 50-56.

6. Minkowitz RB, Bhadsavle S, Walsh M, Egol KA. Removal of painful orthopaedic implants after fracture union. J Bone Joint Surg Am. 2007; 89:1906-12.

7. Pot JH, Remco JA, Olsman JG. Hardware related pain and hardware removal after open reduction and internal fixation of ankle fractures. The Foot and Ankle Online Journal. 2011;4 (5): 1. DOI 10.3827/ faoj.2011.0405.0001.

8. Gajraj NM. The effect of cyclooxygenase-2 inhibitors on bone healing. Reg Anesth Pain Med. 2003;28:456-465. doi:10.1016/j. rapm.2003.09.001
9. Gerstenfeld LC, Einhorn TA. $C O X$ inhibitors and their effects on bone healing. Expert Opin Drug Saf. 2004;3:131-136. doi:10.1517/14740338.3.2.131.

10. Meunier A, Aspenberg P. Parecoxib impairs early metaphyseal bone healing in rats. Arch Orthop Trauma Surg. 2006;26:433-436. doi:10.1007/s00402-006-0160-3.

11. Aspenberg P. Avoid COX inhibitors after skeletal injury! Acta Orthop Scand. 2002:73:489-490. doi:10.1080/000164702321022730.

12. Einhorn TA. COX-2: where are we in 2003? The role of cyclooxygenase- 2 in bone repair. Arthritis Res Ther. 2003;5:5-7. doi:10.1186/ ar607.

13. Dahners LE, Mullis BH. Effects of nonsteroidal anti-inflammatory drugs on bone formation and soft tissue healing. J Am Acad Orthop Surg. 2004;12:139-143.

14. Fitzgerald GA, Patrono C. The coxibs, selective inhibitors of cyclooxygenase. N Engl J Med. 2001;345:433-442. doi:10.1056/ NEJM 200108093450607.

15. Akritopoulos P, Papaioannidou P, Hatzokos I, Haritanti A, Iosifidou E, Kotoula M, et al. Parecoxib has non-significant longterm effects on bone healing in rats when administered for a short period after fracture. Arch Orthop Trauma Surg. 2009;129:14271432. DOI 10.1007/s00402-008-0707-6.

16. Abdul-Hadi O, Panvizi J, Austin MS, Viscual E, Einhorn T. Nonsteroidal anti-inflammatory drugs in orthopaedics. J Bone Joint Surg Am. 2009;91:2020-7.

17. Green E, Lubahn JD, Evans J. Risk factors, treatment, and outcomes associated with nonunion of the midshaft humerus fracture. Journal of Surgical Orthopaedic Advances. 2005; 14(2):64-72. [PubMed: 16115430].

18. Karachalios T, Boursinos L, Poultsides L, Khaldi L, Malizos KN. The effects of the short-term administration of low therapeutic doses of anti-COX-2 agents on the healing of fractures. An experimental study in rabbits. J Bone Joint Surg (Br) 2007;89-B:1253-60.

19. Long J, Lewis S, Kuklo T, Zhu Y, Riew KD. The effect of cyclooxygenase-2 inhibitors on spinal fusion. J Bone Joint Surg Am. 2002;84: 1763-1768.

20. Dimar JR, Ante WA, Zhang YP, Glassman SD. The effect of nonsteroidal anti-inflammatory drugs on posterior spinal fusions in the rat. Spine. 1996;21(16): 1870-1876.

21. Giannoudis PV, Macdonald DA, Matthews SJ. Non-union of the femoral diaphysis. The influence of reaming and NSAIDs. J Bone Joint Surg. 2000;82B:655-658. 
Tody Pinandita, dr : Efek Pemberian Meloxicam yang Diberikan Selama Fase Inflamasi terhadap Proses Penyembuhan Tulang Tikus Paska Open Reduction Internal Fixation K-Wire Dinilai Secara Radiologis

22. Lin C, Jee SS, Ma YF, Setterberg RB. Early effects of prostaglandin E2 on bone formation and resorption in different bone sites of rats. Bone 1995; 17: 255S-259S.

23. Thomas A. Einhorn, MD. Use of COX-2 inhibitors in patients with fractures. Bulletin of Americn Academy of Orthopedic Surgeons 2002;50(5).
24. Gerstenfeld LC, Al-Ghawas M, Alkhiary YM, Cullinane DM, Krall EA, Fitch JL et al. Selective and nonselective cyclooxygenase-2 inhibitors and experimental fracture-healing. Reversibility of effects after shortterm treatment.J Bone Joint Surg Am. 2007;89:114-125. 